\title{
Technical Solutions to Ensure Safe Yttrium-90 Radioembolization in Patients With Initial Extrahepatic Deposition of ${ }^{99 m}$ Technetium-Albumin Macroaggregates
}

\author{
M. W. Barentsz $\cdot$ M. A. D. Vente $\cdot$ M. G. E. H. Lam • M. L. J. Smits \\ J. F. W. Nijsen - B. A. Seinstra • C. E. N. M. Rosenbaum - H. M. Verkooijen • \\ B. A. Zonnenberg • M. A. A. J. Van den Bosch
}

Received: 27 October 2010/ Accepted: 3 December 2010/Published online: 30 December 2010

(C) The Author(s) 2010. This article is published with open access at Springerlink.com

\begin{abstract}
Purpose To evaluate the incidence of extrahepatic deposition of technetium-99m-labeled albumin macroaggregates ( $\left.{ }^{99 \mathrm{~m}} \mathrm{Tc}-\mathrm{MAA}\right)$ after pretreatment angiography, before yttrium-90 radioembolizaton $\left({ }^{90} \mathrm{Y}-\mathrm{RE}\right)$, and to report on technical solutions that can be used to ensure safe delivery of ${ }^{90} \mathrm{Y}$-microspheres in patients with initial extrahepatic deposition.

Materials and Methods A retrospective analysis of 26 patients with primary and secondary liver malignancies, who were scheduled for treatment with ${ }^{90} \mathrm{Y}-\mathrm{RE}$ in our institution in 2009, was performed. The angiograms and single-photon emission computed tomography images of all patients were reviewed by an interventional radiologist and a nuclear medicine physician, respectively, to identify and localize extrahepatic deposition of ${ }^{99 \mathrm{~m}} \mathrm{Tc}-\mathrm{MAA}$ when present. Subsequently, the technical solutions were used to successfully perform ${ }^{90} \mathrm{Y}$-RE in these patients were evaluated and described.

Results Extrahepatic deposition of ${ }^{99 \mathrm{~m}} \mathrm{Tc}-\mathrm{MAA}$ was observed in 8 of 26 patients ( $31 \%$ ). In 7 of 8 patients, a second pretreatment angiography was performed to detect the cause of extrahepatic deposition. The technical solutions to enable
\end{abstract}

M. W. Barentsz · M. L. J. Smits · B. A. Seinstra

C. E. N. M. Rosenbaum - H. M. Verkooijen ·

M. A. A. J. Van den Bosch ( $\square)$

Center of Interventional Oncology and Department

of Radiology, University Medical Center Utrecht,

Heidelberglaan 100, 3584 CX Utrecht, The Netherlands

e-mail: mbosch@umcutrecht.nl

M. A. D. Vente · M. G. E. H. Lam - J. F. W. Nijsen ·

B. A. Zonnenberg

Department of Nuclear Medicine, University Medical Center

Utrecht, 3584 CX Utrecht, The Netherlands safe ${ }^{90} \mathrm{Y}$ microspheres delivery included more distal placement of the microcatheter in the proper/right hepatic artery in 4 of $7(57 \%)$ patients; (super)selective catheterization of multiple segmental branches in 2 of 7 (29\%); and additional coiling of a newly detected branch in the remaining patient $(14 \%)$. This was confirmed by a second MAA procedure. ${ }^{90} \mathrm{Y}$-RE was eventually performed in 25 of 26 (96\%) patients. No procedure-related complications ( $<30$ days) were observed. Conclusion Extrahepatic deposition of ${ }^{99 \mathrm{~m}}$ Tc-MAA after pretreatment angiography did occur in 8 of 26 (31\%) patients. The technical solutions as presented allowed safe ${ }^{90} \mathrm{Y}$-RE delivery in 25 of $26(96 \%)$ patients.

Keywords Yttrium-90 - Radioembolization · Hepatic malignancy · Extra-hepatic deposition · Technetium-Albumin Macroaggregates

\section{Introduction}

Intra-arterial yttrium-90 radioembolization $\left({ }^{90} \mathrm{Y}-\mathrm{RE}\right)$ is increasingly used for treatment of patients with unresectable primary and secondary liver malignancies $[1,2]$. For effective targeting of these tumors, ${ }^{90} \mathrm{Y}$ microspheres are injected into the hepatic artery. This can be performed by (1) placement of a catheter into the proper hepatic artery or into each of the right (RHA) and left hepatic arteries (LHA) separately in the same session (whole-liver treatment) or (2) placement of catheter into each of the RHA and LHA sequentially with an interval of 4 weeks between placements (lobar treatment) [3]. Before ${ }^{90} \mathrm{Y}$-RE, visceral angiography is performed for several reasons: (1) to minutely map out the vascular anatomy of the liver; (2) to visualize extrahepatic vessels branching of the hepatic artery, such as the gastroduodenal artery (GDA) and the 
right gastric artery; and (3) to perform coil embolization of these extrahepatic vessels [4]. Coil embolization is performed to minimize the risk of extrahepatic deposition of ${ }^{90} \mathrm{Y}$ microspheres during treatment. Extrahepatic deposition of ${ }^{90} \mathrm{Y}$ microspheres may cause serious complications, including gastrointestinal ulceration and bleeding, gastritis, duodenitis, and pancreatitis $[3,5-8]$.

To determine that all necessary branches are coiled and to assess the risk of extrahepatic deposition of ${ }^{90} \mathrm{Y}$ microspheres, a test dose of technetium-99 m-labelled albumin macroaggregates $\left({ }^{99 \mathrm{~m}} \mathrm{Tc}-\mathrm{MAA}\right)$ is injected. Subsequently, single-photon emission computed tomography (SPECT) is performed to detect potential deposition in extrahepatic organs as well as to evaluate ${ }^{99 \mathrm{~m}} \mathrm{Tc}-\mathrm{MAA}$ distribution in the liver. Planar nuclear imaging is used to calculate the lung-shunt fraction $[3,5,6]$. Gastrointestinal deposition of ${ }^{99 \mathrm{~m}} \mathrm{Tc}-\mathrm{MAA}$ is an absolute contraindication for ${ }^{90} \mathrm{Y}$-RE because of the previously mentioned complications [9-12].

In the literature, it has not been reported in what percentage of patients extrahepatic deposition of ${ }^{99 \mathrm{~m}} \mathrm{Tc}-\mathrm{MAA}$ is observed during pretreatment angiography nor how to proceed to ${ }^{90} \mathrm{Y}$-RE when extrahepatic deposition is present after angiographic workup, including coil embolization of extrahepatic vessels. No previous studies have described if a second pretreatment angiogram is indicated to detect the cause of extrahepatic deposition. Therefore, the aim of this study was to evaluate the incidence of extrahepatic deposition of ${ }^{99 \mathrm{~m}} \mathrm{Tc}-\mathrm{MAA}$ after pretreatment angiography in patients with primary and secondary liver tumors and to report technical solutions that can be used to ensure safe delivery of ${ }^{90} \mathrm{Y}$-microspheres in these patients.

\section{Materials and Methods}

\section{Study Design and Patient Selection}

The records of 26 patients who were referred to our institution for whole-liver ${ }^{90} \mathrm{Y}$-RE treatment of either primary or secondary liver malignancies were retrospectively analyzed. In all patients, resin-based microspheres (SIRSpheres; SIRTeX Medical Ltd., Sydney, NSW, Australia) were used for ${ }^{90} \mathrm{Y}$-RE. All patients had extensive malignant liver disease, were not eligible for surgical resection, had minor or no extrahepatic disease, and had an acceptable liver performance status [13]. All patients had either progressive disease after first- or second-line chemotherapy and/or had experienced serious side effects from chemotherapy. Clinical data and angiographic findings were compiled from the patients' medical records, and the angiographic images were retrieved from the picture archiving and communication system and re-evaluated.
Procedure

Preangiographic imaging was performed with either computed tomography (CT) or magnetic resonance imaging (MRI) of the liver. If a patient underwent a CT scan, this was preferably a three-phase scan (arterial, portal, and equilibrium phases). ${ }^{90} \mathrm{Y}-\mathrm{RE}$ was preceded by pretreatment angiography to assess the individual vascular anatomy. Angiography was performed through a femoral artery approach using standard $5 \mathrm{~F}$ catheters for catheterization of the celiac axis and the superior mesenteric artery (SMA). Subsequently, a coaxial 2.7F Progreat catheter (Terumo, Leuven, Belgium), including a 0.018-inch guidewire, was used for selective catheterization. Catheterization of the SMA, celiac axis, common hepatic artery, proper hepatic artery, left and RHA was performed in all patients. Extrahepatic arteries branching off the common or proper hepatic artery, such as the GDA, the gastric arteries, and the pancreaticoduodenal branches, were actively searched for and/or identified. A power injector was used for all hepatic angiograms. In general, the flow rate was $5 \mathrm{cc}$ contrast/s, and the total volume of contrast administered was $15 \mathrm{cc}$. Extrahepatic arteries branching off the common or proper hepatic artery were occluded with coil embolization. If these vessels were no longer patent on angiography, approximately $150 \mathrm{MBq}{ }^{99 \mathrm{~m}} \mathrm{Tc}-\mathrm{MAA}$ was injected through the microcatheter, with the tip of the catheter in the proper hepatic artery (whole liver treatment) or in the RHA/LHA (lobar treatment). Subsequently, to assess lung shunting and to detect potential extrahepatic deposition of ${ }^{99 \mathrm{~m}} \mathrm{Tc}-\mathrm{MAA}$, both planar imaging and SPECT was performed. The time interval between ${ }^{99 \mathrm{~m}} \mathrm{Tc}-\mathrm{MAA}$ infusion and SPECT scan was $<30$ minutes to prevent accumulation of free technetium. Fusion of the nuclear images with the pretreatment CT images was performed to identify the distribution of ${ }^{99 \mathrm{~m}} \mathrm{Tc}-\mathrm{MAA}$. If the distribution was demonstrated to be confined to the liver and liver uptake was satisfactory, patients were readmitted within 2 weeks for ${ }^{90} \mathrm{Y}$-RE. During ${ }^{90} \mathrm{Y}-\mathrm{RE}$ treatment, the injection position of the catheter tip was identical to the tip position during the ${ }^{99 \mathrm{~m}} \mathrm{Tc}-\mathrm{MAA}$ infusion. The ${ }^{90} \mathrm{Y}$ microspheres were injected either into both lobes in one session or into the RHA and the LHA sequentially with an interval of 4 weeks. If the SPECT images showed extrahepatic deposition, a second pretreatment angiography was performed to identify the branch(es) presumably accountable for the extrahepatic deposition.

\section{Data Extraction}

The angiograms and ${ }^{99 \mathrm{~m}} \mathrm{Tc}-\mathrm{MAA}$ SPECT images coregistered to the pretreatment CT images of all 26 patients were re-evaluated by an interventional radiologist and a nuclear 
medicine physician, both of whom are board certified. Primary outcome variables were as follows: (1) assessment of individual vascular anatomy, (2) registration of the occluded extrahepatic branches, (3) assessment of extrahepatic deposition of ${ }^{99 \mathrm{~m}} \mathrm{Tc}-\mathrm{MAA}$ according to location, and (4) whether ${ }^{90} \mathrm{Y}$-RE was performed bilobar, unilobar, superselective, or withheld. Based on these data, the strategy used to proceed in patients with initial extrahepatic ${ }^{99 \mathrm{~m}}$ Tc-MAA deposition was determined.

\section{Results}

Twenty-six patients (16 men and 10 women, mean age 59 years) with liver-dominant malignant disease underwent pretreatment angiography to determine whether they were eligible for ${ }^{90}$ Y-RE. Demographics and baseline characteristics are listed in Table 1.

Eight of $26(31 \%)$ patients showed extrahepatic ${ }^{99 \mathrm{~m}} \mathrm{Tc}-$ MAA accumulation after pretreatment angiography. In 7 of 8 patients, extrahepatic deposition was observed in the duodenum and/or pancreas and in 1 of 8 patients in the gastric wall.

Table 1 Baseline patient characteristics

\begin{tabular}{|c|c|c|}
\hline Characteristics & $N$ & $\%$ \\
\hline No. of patients & 26 & 100 \\
\hline Age, median (year) & $59 \pm 6.6$ & NA \\
\hline \multicolumn{3}{|l|}{ Gender } \\
\hline Female & 10 & 38 \\
\hline Male & 16 & 62 \\
\hline \multicolumn{3}{|l|}{ Tumor type } \\
\hline Colorectal cancer metastases & 9 & 35 \\
\hline Neuroendocrine cancer metastases & 5 & 19 \\
\hline Hepatocellular carcinoma & 4 & 15 \\
\hline Cholangiocarcinoma & 3 & 11 \\
\hline Esophageal cancer metastases & 2 & 8 \\
\hline Pancreatic cancer metastases & 1 & 4 \\
\hline Ocular melanoma metastases & 1 & 4 \\
\hline Unknown primary (ACUP) & 1 & 4 \\
\hline \multicolumn{3}{|l|}{ Tumor treatment } \\
\hline Bilobar & 14 & 54 \\
\hline Right unilobar & 11 & 42 \\
\hline Left unilobar & 0 & 0 \\
\hline No treatment & 1 & 4 \\
\hline \multicolumn{3}{|l|}{ Vascular anatomy } \\
\hline Normal & 19 & 73 \\
\hline Right hepatic origin from SMA & 5 & 19 \\
\hline Other & 2 & 8 \\
\hline
\end{tabular}

NA not applicable, ACUP adenocarcinoma of unknown primary
In seven of eight patients, a second angiography was performed to detect branches accountable for the extrahepatic deposition of ${ }^{99 \mathrm{~m}} \mathrm{Tc}-\mathrm{MAA}$. In one patient, this was not performed because the patient was not eligible for ${ }^{90} \mathrm{Y}-\mathrm{RE}$ because there were several small extrahepatic vessels originating from the proper hepatic artery that were not accessible with a microcatheter. The technical solutions to enable safe ${ }^{90} \mathrm{Y}$ microspheres delivery are listed in Table 2. To summarize, these solutions included a more distal placement of the microcatheter in the proper or RHA in four of seven patients $(57 \%)$. In two of seven $(29 \%)$ patients, superselective catheterization of multiple segmental branches was performed. Finally, additional coiling of an initially undetected patent vessel arising from the proper hepatic artery was performed in one of seven patients (14\%). Figure 1 shows an example of this approach.

In these seven patients, no extrahepatic ${ }^{99 \mathrm{~m}} \mathrm{Tc}-\mathrm{MAA}$ deposition was observed on SPECT images after the second pretreatment angiography and injection of ${ }^{99 \mathrm{~m}} \mathrm{Tc}$ MAA. During ${ }^{90} \mathrm{Y}-\mathrm{RE}$ treatment, the injection position of the catheter tip was identical to the tip position during ${ }^{99 \mathrm{~m}} \mathrm{Tc}-\mathrm{MAA}$ infusion. In the total group of 26 patients who were eligible for ${ }^{90} \mathrm{Y}-\mathrm{RE}$ and underwent pretreatment angiography, 25 were finally treated with ${ }^{90} \mathrm{Y}(96 \%)$. Of all treated patients, 5 of 25 patients reported fatigue, and 2 of 25 patients reported self-limiting abdominal pain. No directly procedure-related complications ( $<30$ days) were observed.

\section{Discussion}

This study shows that a significant percentage of patients [8 of $26(31 \%)$ ] who were scheduled for whole-liver ${ }^{90} \mathrm{Y}$-RE and who underwent pretreatment angiography and ${ }^{99 \mathrm{~m}} \mathrm{Tc}$ MAA injection presented with unforeseen extrahepatic deposition on the SPECT images. In 7 of 8 patients diagnosed with extrahepatic deposition, an additional pretreatment angiography was performed to assess the probable cause of extrahepatic deposition. In all seven patients, the cause for extrahepatic deposition was identified.

Intra-arterial radioembolization with ${ }^{90} \mathrm{Y}$ microspheres is increasingly used in clinical practise, and its therapeutic effect is subject to evaluation in several ongoing phase II and III clinical trials. To our knowledge, no previous studies have reported the incidence of extrahepatic deposition of ${ }^{99 \mathrm{~m}} \mathrm{Tc}-\mathrm{MAA}$ after pretreatment angiography. The technical solutions that we used in our patients to solve the problem of extrahepatic deposition included more distal positioning of the catheter $(n=4)$, superselective catheterization of multiple segmental branches $(n=2)$, and additional coiling of a patent vessel arising from the proper 
Table 2 Technical solutions for eight cases of extrahepatic ${ }^{99 m}$ Tc-MAA deposition

\begin{tabular}{|c|c|c|c|c|c|c|c|}
\hline $\begin{array}{l}\text { Patient } \\
\text { no. }\end{array}$ & Diagnosis & $\begin{array}{l}\text { Vascular } \\
\text { anatomy }\end{array}$ & $\begin{array}{l}\text { Coiled } \\
\text { arteries }\end{array}$ & $\begin{array}{l}\text { Injection } \\
\text { site }\end{array}$ & $\begin{array}{l}\text { Site of } \\
\text { extrahepatic } \\
\text { deposition }\end{array}$ & Cause & Solution \\
\hline 1 & $\mathrm{HCC}$ & Normal & GDA & RHA & Duodenum & $\begin{array}{l}\text { Suboptimal coiling } \\
\text { GDA with proximal } \\
\text { branch }\end{array}$ & $\begin{array}{l}\text { Selective catheterization: more } \\
\text { distal in RHA (lobar) }\end{array}$ \\
\hline 2 & $\begin{array}{l}\text { Liver metastasis of } \\
\text { neuroendocrine } \\
\text { pancreatic tumor }\end{array}$ & $\begin{array}{l}\text { Right- } \\
\text { hepatic } \\
\text { artery } \\
\text { originating } \\
\text { from SMA: } \\
2 \text { sessions }\end{array}$ & GDA & RHA & $\begin{array}{l}\text { Duodenum/ } \\
\text { head of } \\
\text { pancreas }\end{array}$ & $\begin{array}{l}\text { Injection through } \\
\text { glide-catheter, no } \\
\text { microcatheter; } \\
\text { injection too } \\
\text { proximal? }\end{array}$ & $\begin{array}{l}\text { New }{ }^{99 m} \text { TC-MAA injection with } \\
\text { microcatheter to bifurcation } \\
\text { right and median hepatic }\end{array}$ \\
\hline 3 & $\begin{array}{l}\text { CRCLMs }+ \\
\text { left-sided } \\
\text { hemihepatectomy }\end{array}$ & $\begin{array}{l}\text { Trifurcation } \\
\text { of the } \\
\text { proper } \\
\text { hepatic } \\
\text { artery }\end{array}$ & GDA & $\begin{array}{l}\text { Proper } \\
\text { hepatic } \\
\text { artery }\end{array}$ & $\begin{array}{l}\text { Head of } \\
\text { pancreas }\end{array}$ & $\begin{array}{l}\text { From proper hepatic } \\
\text { three vessels: no } \\
\text { extra coiling } \\
\text { performed }\end{array}$ & $\begin{array}{l}\text { New }{ }^{99 m} \text { TC-MAA injection with } \\
\text { selective catheterization in } \\
\text { three segmental branches ( } 3 \\
\text { injections) }\end{array}$ \\
\hline 4 & $\begin{array}{l}\text { CRCLMs + } \\
\text { left-sided } \\
\text { hemihepatectomy }\end{array}$ & Normal & GDA & RHA & $\begin{array}{l}\text { Duodenum/ } \\
\text { head of } \\
\text { pancreas }\end{array}$ & $\begin{array}{l}\text { Small branch to } \\
\text { duodenum: too } \\
\text { small to coil }\end{array}$ & $\begin{array}{l}\text { New }{ }^{99 m} \text { TC-MAA injection: } \\
\text { distal from branch }\end{array}$ \\
\hline \multirow[t]{3}{*}{5} & CRCLMs & Normal & $\begin{array}{l}\text { GDA and } \\
\text { right } \\
\text { gastric } \\
\text { artery }\end{array}$ & $\begin{array}{l}\text { Two } \\
\text { sessions: } \\
\text { small } \\
\text { branch to } \\
\text { duodenum }\end{array}$ & & & \\
\hline & & & & RHA & $\begin{array}{l}\text { Duodenum/ } \\
\text { head of } \\
\text { pancreas }\end{array}$ & $\begin{array}{l}\text { Small branch to } \\
\text { duodenum } \\
\text { (accountable for } \\
\text { deposition) }\end{array}$ & Coiling duodenal branch \\
\hline & & & & LHA & & & \\
\hline 6 & ACUP & Normal & $\begin{array}{l}\text { GDA and } \\
\text { right } \\
\text { gastric } \\
\text { artery }\end{array}$ & $\begin{array}{l}\text { Proper } \\
\text { hepatic } \\
\text { artery }\end{array}$ & Duodenum & $\begin{array}{l}\text { Small branch to } \\
\text { duodenum: too } \\
\text { small to coil }\end{array}$ & $\begin{array}{l}\text { New }{ }^{99 m} \text { TC-MAA injection with } \\
\text { selective catheterization in two } \\
\text { phases: no extra hepatic } \\
\text { deposition in either }\end{array}$ \\
\hline 7 & $\mathrm{HCC}$ & Normal & GDA & RHA & $\begin{array}{l}\text { Head of } \\
\text { pancreas }\end{array}$ & $\begin{array}{l}\text { Small branch to head } \\
\text { of pancreas: too } \\
\text { small to coil }\end{array}$ & $\begin{array}{l}\text { New }{ }^{99 m} \text { TC-MAA injection: } \\
\text { more distal from branch }\end{array}$ \\
\hline 8 & $\mathrm{HCC}$ & $\begin{array}{l}\text { Normal, } \\
\text { numerous } \\
\text { side } \\
\text { branches }\end{array}$ & $\begin{array}{l}\text { GDA, } \\
\text { cystic } \\
\text { artery, \& } \\
\text { duodenal } \\
\text { branch }\end{array}$ & $\begin{array}{l}\text { Proper } \\
\text { hepatic } \\
\text { artery }\end{array}$ & $\begin{array}{l}\text { Gallbladder/ } \\
\text { gastric } \\
\text { wall }\end{array}$ & $\begin{array}{l}\text { Numerous side } \\
\text { branches }\end{array}$ & No ${ }^{90} \mathrm{Y}$-RE possible: TACE \\
\hline
\end{tabular}

CRCLMs colorectal carcinoma liver metastasis, ACUP adenocarcinoma of unknown primary

hepatic artery $(n=1)$. Absence of extrahepatic deposition of ${ }^{99 \mathrm{~m}}$ Tc-MAA was confirmed in all seven patients with a second SPECT scan. As a consequence, 25 of 26 patients underwent whole-liver ${ }^{90} \mathrm{Y}$-RE.

Parallel to our findings, different groups have advocated ${ }^{90} \mathrm{Y}$-RE administered in a "bilobar lobar" fashion to avoid the high incidence of extrahepatic deposition in patients scheduled for whole-liver ${ }^{90} \mathrm{Y}-\mathrm{RE}$ from the proper hepatic artery [3]. This approach of treating the whole liver of a patient in one session is also recommended with regard to cost-effectiveness. In this manner, fewer angiographic procedures have to be performed, and only one dose of ${ }^{90} \mathrm{Y}$ has to be ordered.
More recently, it has been advised to use cone-beam CT during pretreatment angiography to facilitate proper catheter position for treatment [14]. If during the pretreatment angiography, probable deposition outside the liver occurs, cone-beam CT may provide guidance in determining which specific arterial branch perfuses a particular organ. This provides the opportunity to identify, and subsequently coil, branches that may otherwise be accountable for extrahepatic deposition and therefore decrease the likelihood of positive ${ }^{99 \mathrm{~m}}$ Tc-MAA SPECT. Becker et al. [15] advocated the use of cone-beam CT for this reason, which may add decisive information in patients scheduled for ${ }^{90} \mathrm{Y}-\mathrm{RE}$ and can have an impact on the procedure itself. 

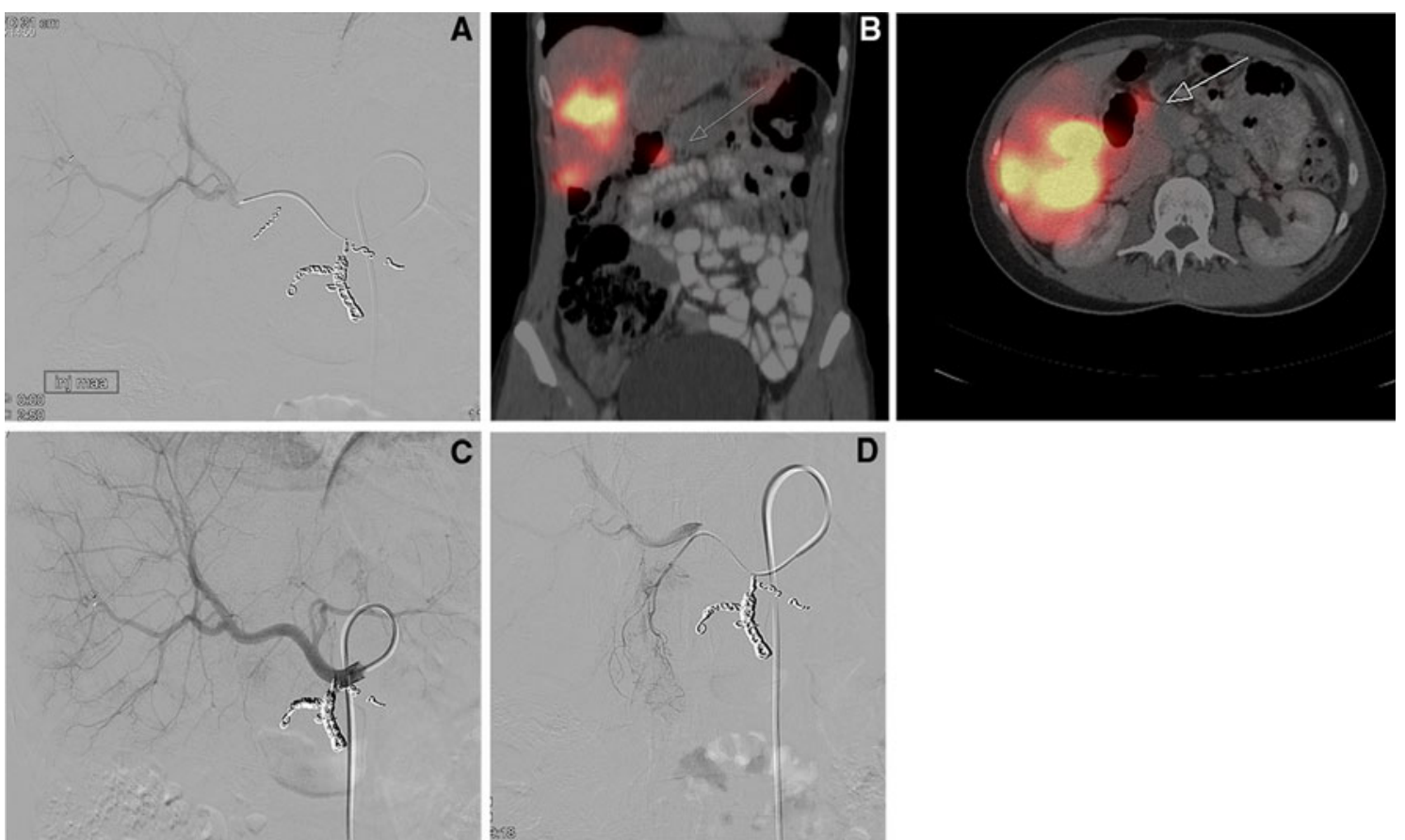

Fig. 1 A Initial angiogram of the common hepatic artery after coiling of the GDA. B SPECT/CT fusion images of the liver, after ${ }^{99 \mathrm{~m}} \mathrm{TC}$ MAA injection, suggesting extrahepatic uptake (indicated by the arrow). C Second angiogram with the microcatheter in the branch causing extrahepatic deposition in duodenum/head of pancreas on SPECT. D Angiogram with injection of ${ }^{99}$ Tc-MAA after subsequent coiling of the small pancreaticoduodenal branch

One other aspect that must be taken into consideration is an altered vascular anatomy in patients who were previously treated with partial hepatic resection. Two of 26 patients in our study underwent hemihepatectomy, and both patients had deposition of ${ }^{99 m}$ Tc-MAA outside the liver. In these 2 patients, we observed a vascular anatomy with numerous neovascular branches, very small in diameter, that presumably had been formed as a consequence of the liver surgery. No literature could be found to support this assumption. It has been reported that after liver surgery, due to inflammatory response, neovascularization of the vascular bed is stimulated [16]. Animal studies in mice have shown that microvessel density increases in the liver remnant after hepatectomy in $70 \%$ of the operated mice [17]. We therefore emphasize that extra attention should be given to the vascular anatomy in patients who have undergone liver surgery, for whom superselective ${ }^{90} \mathrm{Y}-\mathrm{RE}$ may be the strategy of first choice.

To visualize aberrant vessels coming of branches of the hepatic artery, we also recommend the use of contrast injection with a power injector. For images of (vessels branching from) from the proper hepatic artery, we used a flow rate of $5 \mathrm{cc} / \mathrm{s}$ and a total dose of $15 \mathrm{cc}$. For segmental branches, we switched to a flow rate of 2 to $3 \mathrm{cc} / \mathrm{s}$ and a total dose of 10-12 cc.

It is imperative to ensure that possible extrahepatic deposited ${ }^{99 \mathrm{~m}}$ Tc-MAA indeed is located outside the liver. In our center, we had to use SPECT/CT-fusion images to determine extrahepatic deposition of ${ }^{99 m}$ Tc-MAA. However, the SPECT and CT images were not recorded simultaneously, so both are subject to various influences. Gastric filling, for example, can differ during both procedures and may influence the positioning of abdominal organs, especially in oral contrast-enhanced CT imaging. Correct fusion of the SPECT and CT images may therefore be difficult or even impossible, and deposition of ${ }^{99 m}$ Tc-MAA may be falsely concluded to be present. It is important to perform pretreatment three-phase CT and SPECT within a reasonable time frame. A dedicated SPECT/CT system, i.e., a gamma camera combined with an integrated low-dose computed tomograph, could increase both sensitivity and specificity in detecting extrahepatic ${ }^{99 \mathrm{~m}}$ Tc-MAA accumulation [18].

One of the limitations of this study is the short-term follow-up of 30 days. Although we believe that all procedure-related complications may become manifest within this time frame, gastrointestinal ulcers with a delayed presentation may potentially have been missed. Furthermore, possible gain in terms of decreased treatment time and decreased procedure-related costs may have been offset by the relative high number $(31 \%)$ of readmissions for a second ${ }^{99 m}$ Tc-MAA procedure. This study was not designed to compare different treatment strategies, i.e., proximal wholeliver treatment versus selective whole-liver treatment, but this may be an interesting issue for further research. 
In conclusion, extrahepatic deposition of ${ }^{99 \mathrm{~m}} \mathrm{Tc}-\mathrm{MAA}$ does occur in some patients undergoing angiographic workup for ${ }^{90} \mathrm{Y}-\mathrm{RE}$. Our data suggest (1) that these patients should receive one additional angiographic procedure to detect previously undetected patent extrahepatic vessels arising from the hepatic artery and (2) that the possibility of a more selective (e.g., distal) placement of the catheter for injection of ${ }^{99 \mathrm{~m}}$ Tc-MAA should be evaluated. By applying these strategies, ${ }^{90}$ Y-RE can be performed safely. In our case series, no signs were observed related to extrahepatic radioactivity in any of our patients after administration of ${ }^{90} \mathrm{Y}-\mathrm{RE}$.

\section{Conflict of interest None.}

Open Access This article is distributed under the terms of the Creative Commons Attribution Noncommercial License which permits any noncommercial use, distribution, and reproduction in any medium, provided the original author(s) and source are credited.

\section{References}

1. Salem R, Thurston KG (2006) Radioembolization with yttirum90 microspheres: a state-of-the-art brachytherapy treatment for primary and secondary liver malignancies: part 3: comprehensive literature review and future direction. J Vasc Interv Radiol 17: $1571-1593$

2. Vente MAD, Wondergem M, van der Tweel I et al (2009) Yttrium-90 microspheres radioembolization for the treatment of liver malignancies: a structured meta-analysis. Eur Radiol 19: 951-959

3. Salem R, Thurston KG (2006) Radioembolization with 90yttrium microspheres: a state-of-the-art brachytherapy treatment for primary and secondary liver malignancies. Part 2: special topics. J Vasc Interv Radiol 17:1425-1439

4. Lewandowski RJ, Sato KT, Atassi B et al (2007) Radioembolization with ${ }^{90} \mathrm{Y}$ microspheres: angiographic and technical considerations. Cardiovasc Interv Radiol 30:571-592

5. Murthy R, Nunez R, Szklaruk J et al (2005) Yttrium-90 microsphere therapy for hepatic malignancy: devices, indications, technical considerations, and potential complications. Radiographics 25(Suppl 1):S41-S55
6. Murthy R, Brown DB, Salem R et al (2007) Gastrointestinal complications associated with hepatic arterial Yttrium-90 microsphere therapy. J Vasc Interv Radiol 18:553-561

7. Carretero C, Munoz-Navas M, Betes M et al (2007) Gastroduodenal injury after radioembolization of hepatic tumors. Am J Gastroenterol 102:1216-1220

8. Leung TW, Lau WY, Ho SK et al (1995) Radiation pneumonitis after selective internal radiation treatment with intraarterial 90yttrium-microspheres for inoperable hepatic tumors. Int J Radiat Oncol Biol Phys 33:919-924

9. Wong CY, Savin M, Sherpa KM et al (2006) Regional yttrium-90 microsphere treatment of surgically unresectable and chemotherapy-refractory metastatic liver carcinoma. Cancer Biother Radiopharm 21:305-313

10. Jakobs TF, Hoffmann RT, Poepperl G et al (2007) Mid-term results in otherwise treatment refractory primary or secondary liver confined tumours treated with selective internal radiation therapy (SIRT) using (90)Yttrium resin-microspheres. Eur Radiol 17:1320-1330

11. Gulec SA, Mesoloras G, Dezarn WA et al (2007) Safety and efficacy of Y-90 microsphere treatment in patients with primary and metastatic liver cancer: the tumor selectivity of the treatment as a function of tumor to liver flow ratio. J Transl Med 5:15-23

12. Garin E, Rolland Y, Boucher E et al (2010) First experience of hepatic radioembolization using microspheres labelled with yttrium-90 (TeraSphere): practical aspects concerning its implementation. Eur J Nucl Med Mol Imaging 37:453-461

13. Kennedy A, Nag S, Salem R et al (2007) Recommendations for radioembolization of hepatic malignancies using yttrium-90 microsphere brachytherapy: a consensus panel report from the radioembolization brachytherapy oncology consortium. Int $\mathrm{J}$ Radiat Oncol Biol Phys 68:13-23

14. Louie JD, Kothary N, Kuo WT et al (2009) Incorporating conebeam $\mathrm{CT}$ into the treatment planning for yttrium-90 radioembolization. J Vasc Interv Radiol 20(5):606-613

15. Becker C, Waggershauser T, Tiling R, et al. (2010) C-arm computed tomography compared with positron emission tomography/computed tomography for treatment planning before radioembolization. Cardiovasc Intervent Radiol. doi:10.1007/ s00270-010-9897-8

16. van der Bilt JD, Borel Rinkes IH (2004) Surgery and angiogenesis. Biochim Biophys Acta 1654:95-104

17. Drixler TA, Vogten JM, Ritchie ED et al (2002) Liver regeneration is an angiogenesis associated phenomenon. Ann Surg 236: 703-711

18. Hamami ME, Poeppel TD, Muller S, Heusner T et al (2009) SPECT/CT with 99mTc-MAA in radioembolization with $90 \mathrm{Y}$ microspheres in patients with hepatocellular cancer. J Nucl Med 50:688-692 